\title{
Compressed Bricks Made of Makabaye and Pitoaré Clay: Implementation and Production
}

\author{
Benedicte Touogam Touolak1, Fridolin Tchangnwa Nya ${ }^{1,2^{*}}$, Emmanuel Ngale Haulin1, \\ Etienne Yanne ${ }^{1}$, Jean Marie Ndjaka ${ }^{3}$ \\ ${ }^{1}$ Department of Materiel Processing, Architecture and Habitat, Higher Institute of the Sahel, Maroua, Cameroon \\ ${ }^{2}$ Department of Physics, Faculty of Sciences, University of Maroua, Maroua, Cameroon \\ ${ }^{3}$ Department of Physics, University of Yaoundé I, Yaoundé, Cameroon \\ Email: ${ }^{\text {nyafridolin@yahoo.fr }}$
}

Received 13 March 2015; accepted 12 June 2015; published 16 June 2015

Copyright (C) 2015 by authors and Scientific Research Publishing Inc.

This work is licensed under the Creative Commons Attribution International License (CC BY). http://creativecommons.org/licenses/by/4.0/

(c) (i) Open Access

\section{Abstract}

In a strong commitment to economic valorisation that began a decade and relevant contribution to the problems of housing and creation of small jobs response, the Cameroonian government has invested heavily in promoting use of local materials through the creation of MIPROMALO (Mission for Promotion of local Materials) in 1991 (economic crisis), and through the signing of government circular from the Prime Minister, thus placing its development policies in prior to any development strategy more distant prospect. It was then that housing through development of local building materials becomes one of major policy priorities of Cameroonian's government. However, there is a low valuation thereof despite availability of local materials and political will expressed in Circular No. 002/CAB/PM of 12 March 2007 on the use of local materials in construction of public buildings. In this study, we analyse the contribution that can play promotion of local materials in construction in the Sahel zone which for a harmonious sustainable development. Specifically, it's to highlight the added value of using local materials, propose strategies for implementation and production of compressed bricks. This scientific work has therefore a double interest, scientific and technological industrial view and contributes to the development, promotion of local materials and the development of soil and/or basement areas. We arrived after analysis of our data to the conclusion that valuation of clay materials from Maroua's town was a factor for economic growth and sustainable development. This inventory allows us to implement and produce prototypes suitable compressed bricks, shapes of housing in Sahel zone. However, physical and geotechnical tests on materials clay (raw materials for production of bricks), allow us to better assess characteristics of clay before production of bricks. Well after we submit our bricks to various mechanical and technological tests to assess their ability to withstand loads in extreme temperature conditions of Sahel zone.

${ }^{*}$ Corresponding author.

How to cite this paper: Touogam Touolak, B., Tchangnwa Nya, F., Ngale Haulin, E., Yanne, E. and Ndjaka, J.M. (2015) Compressed Bricks Made of Makabaye and Pitoaré Clay: Implementation and Production. Advances in Materials Physics and Chemistry, 5, 191-204. http://dx.doi.org/10.4236/ampc.2015.56020 


\title{
Keywords
}

\author{
Brick, Sahelian Zone, Housing, Local Materials, Labour-Based Technology, High Intensity Hands \\ Work
}

\section{Introduction}

Brick is not only a building material, it combines creativity and modernity. Their shapes have evolved over time: full brick kneaded by our ancestors through neolithic light bricks, finally to those with highly capacity for efficient thermal insulation. The idea of getting a resistant building material from clay is very old and this tradition has continued to this day. Also, this wonder of nature did not leave indifferent African populations, especially those from Cameroon and especially the people of Far North region of Cameroon, who quickly realised need for its use in housing construction. Thus, for nearly twenty years, most of the Far North uses mud bricks for construction. However, despite creation of MIPROMALO (Mission for Promotion of Local Materials) to initiate local development through creation of small jobs, we still observed many failures at the implementation and production of bricks by populations of the Far North region in general, and those of Maroua city in particular [1]-[5]. A local material can be defined as any natural material extracted and/or possibly transform in the country. Here, transformation process may involve imported inputs that don't exceed $20 \%$ of total raw material costs. In doing so, these imported inputs are used only in cases where they may not be available (physical availability and/or technological). Generally, they are classified into three groups according to their origin: Minerals Processing; organic materials (animal or vegetable origin); and manufactured materials [6]-[9].

This research provides answers to some questions of fundamental interest, technological and/or applied science. Examples: Available land wills him a good building material? Is it suitable for production of stabilised soil blocks? Of bricks clay? Or tiles? What is ideal mix of raw materials? What is the best stabiliser? What is the resistance of finished product? What are other potential areas of exploitation of natural materials analysed? In this context, characterisation studies and promotion of local building materials should be supported and involve technological innovation.

\subsection{Brick Land Housing in Sahel Zone}

\subsubsection{Mud Brick}

Vitruve in his work talks about the land and its beneficial solutions to raise fortification walls. It is therefore to upgrade the first building material of history, modernise its image and promote its many advantages for buildings of tomorrow. This claim in the context of universal value of earthen architecture as both heritage, and contemporary as compelling solution for a future "eco-responsible". In other lands, within the School of Architecture of Grenoble CRAterre, International Centre for Earth Construction focuses on the most environmentally friendly and most widespread materials. They recently collaborated on the exhibition "My first earth" in Science City in Paris. They are the authors of petition "Living Earth" manifesto for the right to build in mud. Renowned architects like Anna HERINGER, Martin Rauch and Francis DIEBETO KERE, make the earth preferred material of their buildings both human, sensitive, ecological and contemporary [10]-[18].

\subsubsection{Terracotta Brick}

It is no coincidences that for centuries, materials clay are shaping European built environment; reveals the Belgian Federation of Brick. Starting from a natural raw material-clay-brick clay is a building material more efficient, which can meet all requirements of thermal and acoustic comfort, safety, durability, and "flexibility" building. M. Kornmann and CTTB in his book Building Materials earthenware, manufacturing and properties, sets the clay as part of oldest man-made building materials. For centuries in many countries, terracotta brick was a basic element for construction of houses and public buildings. Born of earth and fire, she has seduced generations of builders. Going in same direction, the use of baked brick knows no limit to its almost architectural use today, and for a long time. It was then that Philippe LAFAURIE in Building terracotta manufacture and properties says that everyone knows that this material is multimillennial (Is it not written that God himself would have made the man from clay, the 6th day of creation of the world?). Everyone has a story and a personal experience 
with clay. This makes it eminently cultural and friendly material. Brick is a source of education [10]-[18].

\subsubsection{Compressed Earth Blocks "BTC"}

Rooted in initial concern to provide a relevant response to new economic and social, to produce housing for poorest people, the technology of compressed earth block as Hugo Houben and Hubert Guillaud, CRATerreresearchers, has not failed in this concern by developing its scope. They claim that these are indeed tens of thousands of family or collective housing, equipment Education and Health have been made since the early 50's, which gave birth to this material in its current form in the center of Bogota, Colombia. Single material, directly inherited from ancient cultures constructive mud brick and baked brick, the BTC is a gifted material in the same constructive and architectural intelligence, the same adaptability to a wide register of determinants physical, ecological, social, economic and technical condition of the built environment production. It is also imposed by evidence he gave its usefulness. Technique of compressed earth block today offers a reliable alternative to an accessible architecture. The compressed earth block is one of few "modern materials" including flexibility production, that allowed its inclusion in public housing programs and private business sectors, formal and informal [10]-[18].

\subsection{Location of the Study Area of Materials Clay}

\subsubsection{Mayo-Tsanaga Site (Makabaye)}

Makabaye is a square in city of Maroua located in the Far North Region with an estimated $404 \mathrm{~m}^{2}$ approximate area. Its geographical coordinates known are " $10^{\circ} 33^{\prime} 48.32$ " in north latitude and " $14^{\circ} 20^{\prime} 53.32$ " in east longitude. It's mainly rural population for the most practical agricultural, commercial and a few cattle breeding. However Makabaye area crossed by two (02) Mayos: Kaliao and Tsanaga. The population of the town along Mayo-Tsanaga does not fail to indulge in lucrative activities primarily in Mayo. Including the extraction of materials clay by women for manufacture of ceramic products, and for marketing [19] [20].

Description of sampling wells

In this site, sampling was carried out in three drilled wells with hand auger. Note however that the region of Mayo-Tsanaga is known for sandy clay nature of the soils.

\subsubsection{Pitoare Site}

Pitoare is located at " $10^{\circ} 35^{\prime} 43.3^{\prime}$ " north latitude and " $14^{\circ} 18^{\prime} 52.8^{\prime}$ " east longitude. However, it is squared by large tree-lined avenues that bring a bit of freshness to lower high temperatures. Fairly diverse population engages in agricultural and industrial trade, crafts, among surrounding communities bordering the Pitoaré area. We include: Dingui, Zayka, Domayo Yong Kollé, Pallars, IDAO, Zokok, Djarengol, Bellare, Makabaye, Zala, Zaki [21].

Description of sampling wells

In this site, sampling was also carried out in three drilled wells with hand auger. Not far from type of soil meet in Kongola-Djiddéo, the floor of Pitoaré area is also known for its clay content.

\section{Literature Review}

\subsection{Current Context of the Promotion of Local Building Materials in Cameroon}

Concerned about the well-being of its population (social housing) and its local development (creation of small jobs), The Cameroonian government is heavily involved in promoting the use of local materials through creation of (Mission Promotion of local Materials) MIPROMALO in 1991 (economic crisis), and the signing of government circular 002/CAB/PM of March 12, 2007 by the Prime Minister Head of Government. This circular established the use of local materials in construction of public buildings. The design offers procurement should now incorporate use of local materials. In addition to this, housing (ownership) has become one of the policy priorities of Cameroon government. In same vein, government set up a semi-industrial plant for production of baked bricks already functional in Yaoundé and Douala. Under a second, as part of the government's construction of 10,000 housing and Planning 50,000 building plots in the country, coordinated by Ministry of Urban Development and Housing (MINHDU) for a large-scale production. The concept of "promotion of local building materials” is therefore thus not new. Indeed ACCETTA André Doctor of Physical Sciences is also a specialist in valorisation of local materials, especially materials in mud. He is currently building a monastery in mud in Cameroon (Koutaba), with Cistercian monks [22]-[29]. 
From this point of view, Cameroon in particular the region of Far North would gain through exploitation of local materials. As explained by the same author, huge site which it refers (e.g. village of Koutaba) will be the ideal opportunity to learn and master modern construction techniques, based on improvement of traditional know-how as a model of sustainable development.

\subsection{Example of a Cameroonian Institution Working in Development of Local Materials in Cameroon: MIPROMALO}

Mission promotion of local materials (MIPROMALO) conducted original research and offers some interesting innovations and proven expertise in field of valorisation local materials. Among the salient results of this institution that works effectively in promotion of local building materials, we can mention: geological identification and characterisation of more 100 deposits of raw materials (clay, limestone, laterite); developing an alternating pozzolana cement; involvement in government program of construction of 10,000 housing units and 50,000 land plots of building land; construction of semi-industrial unit for production of fired bricks clay, with a capacity of 30,000 bricks and with a groove drying 200,000 bricks; development of processes for manufacturing refractory products clay in Mayouom (Fumban) and Mvan (Yaoundé); development of methods making porcelain with local clay; design and implementation of wood kiln and solar drying protocol development species of tropical timber; design and implementation of a press for compressed earth blocks and crusher aggregate; development of a production method of silica used in liquid-solid chromatography; published more than 10 scientific papers and a dissertation on local materials; development and validation of production processes baked bricks, compressed earth blocks, micro-concrete roofing tiles, tile cement aggregates, production of fine pottery and ceramics; design and implementation of special blocks to reduce construction costs; technical manuals for technology transfer; preparation of business plan on installing production units of local materials; training more than 1500 Cameroonian production of baked mud bricks; development of local materials in construction projects: schools, colleges, private houses, buildings for associations, etc. contribution to the development of standards on Cameroonian terracotta bricks and rebar; support the completion of these use of local materials (at least 20 students funded since 2006); creation of a Bureau of Engineering to assist developers in studies and projects on installations of local materials; assistance of Yaoundé University I in the development and practical work in ceramics and glass, in collaboration with National School of Industrial Ceramics (Ensci) Limoges in France; contribution to the studies that led to signing in March 2007 of the Prime Minister's circular, requiring use of local materials in construction of public buildings; establishment of a center for Research and Engineering (PRI), for development of Central Africa in collaboration with the Euro Access and Graduation ISMANS (France) consortium [30]-[34].

\section{Materials and Methods}

The raw materials extraction and technological requirements depend on different sectors of ceramics which falling into two groups. They are: ceramic "gross" or "construction” which includes the sectors of bricks and tiles, pipes clay, refractory clay and aggregates expanded. The group of "fine ceramics” or “ceramic traditional and industrial," which includes areas of tiles for walls and floors, ornamental ceramics, sanitary ware, technical ceramics and inorganic bonded abrasives [35]-[38].

To carry out such a study, it requires the use of sophisticated and appropriate materials. This includes various identification devices, geotechnical apparatus such as: Casagrande, mold and Proctor lady, an oven, an electronic scale, standard sieves, chronometers. We also felt the need to use small equipment for field test dug up including: a measuring tape, a digital camera, bags and plastic bags, a field notebook, a pen, a pickaxe, an auger manual, GPS, and vehicle brand land Rover.

In our study, extraction of raw materials clay involved following process: discovery of bulldozer; excavator loader and scraper; extraction of materials clay and transport to the laboratory. We also have use technological requirements based on the size and chemical composition. Here, the size composition of clay therefore accounts for a significant share of their abilities shaping, drying and firing.

\subsection{Description of Methods Use to Select Our Samples Clay for Bricks Formulation}

\subsubsection{Chemical and Mineralogical Composition}

To avoid harmful in the raw material, especially if it is intended for the production of building materials brick 
and tile type elements include: coarse chalk that turns during cooking quicklime; these nodules are breaking the product in presence of moisture; soluble salts (sulphates) crystallise on surface to reduce the volume of cooking, and in the rain hydrate popping mass (efflorescence problems); organic impurities burning cooking leaving voids in porous mass from which products; loose stones wholesale grains burst during cooking. In the field of ceramics, plasticity is one of desired properties because it facilitates manufacturing (especially shaping) of ceramic products [39]-[41].

\subsubsection{Influence of Forming Water Temperature}

A rise in water temperature shaping a positive action. Indeed, within a porous body, water tends to migrate from the hot side to the cold side. To facilitate the spread in raw commodity, we must act on the temperature gradient. Indeed, it is necessary to compensate evaporated water to the surface from which pores and migrating under effect of capillary forces. Now, at the beginning of a regular drying process to avoid "crust" on the surface, it is the heating of room to dry that we must first spend time. The whole process is slowed with increased danger of cracking, if dough is relatively dense, massive room, or if volume-area ratio is unfavorable. In contrast, with preheating steam, from die outlet, the temperature gradient is no longer opposed to capillary migration, since heart of the piece can be hotter than evaporation surface [42]-[44].

\subsection{Manufacturing Processes of Our Study}

The steps for producing ceramic products are similar. They include preparation, shaping, drying, any surface treatments and cooking [45]-[48]. The following steps productions of ceramic products are illustrate from the paragraphs below.

\subsubsection{Preparation}

It requires various operations that differ somewhat depending on the material available and the degree of plasticity of desired type and paste manufacture. As operations we have: pre-drying and pre-mix, here certain raw materials such as sand need to be pre-dried by a fluidised bed or by rotary kilns; we also have crushing and grinding primary, here an initial coarse crushing of relatively dry or crumbly clay can be made by crushing rollers with big teeth, usually located in the quarry, which also serve to fragment the harsh raw materials used in manufacture of refractory products; another operation is grinding, here finer particles required in applications such as ceramic tiles for floors and walls, refractory products and tableware, roller mills are used dry or wet roads; screening and classification is an operation to optimise certain ceramics properties (e.g. density), it is sometimes necessary to mix some sizes of materials, dry screening is generally to use vibrating sieve, which electrically heated to prevent build-up of material and clogging; mixing components is an operation which raw materials prepared in controlled, required uniformity Physicochemical depending on the ceramic sector, the mixture can vary between continuing operations, and large-scale batch controlled small-scale mixing; and finally, specific formulations may be necessary in manufacture of ceramic products, this is case of the calcination (e.g. dolomite or magnesite for refractory manufacture), the preparation of enamel and synthetic raw materials (e.g. silicon carbide).

\subsubsection{Shaping}

Primary role of this operation is to provide the clay paste sufficient cohesion to the latter may be shaped in the form of said finished products. The second role is to give the clay mass not only desired shape, but also the strength in sec. As different operation of shaping, we have: pressing which is a technique of shaping ceramic products that can be mechanical, hydraulic, friction, impact or rebound, this method is used in the areas of refractory and techniques as well as in the manufacture of tiles, and tableware ceramics; we also have extrusion which is commonly used for continuous and large-scale manufacturing of bricks (perforated products) and light masonry blocks, clay pipes, slabs, tiles and ceramic tiles for floors and walls, it requires a plastic raw material, so clay content important; moulding clay products is an operation which require much less power and energy than pressing or extrusion, but it takes a much softer mixture (wet), which leads to more drying shrinkage and energy input heat greater than the drying; finally we have slipcasting which is a molding technique widely used in manufacture of sanitaryware, tableware, decorative items, and for the manufacture of technical ceramics and special complex refractories. 


\subsubsection{Drying}

The drying is to remove water slowly and optionally forming water contained in the base material clay, without deforming product and enable its handling and stacking. Today, the heat of drying air is mainly supplied by gas burners and hot air recovered by the cooling zone of furnace. We have natural drying which is practiced by exposing finished products in warehouses light outdoors. This requires large areas of drying and a significant amount of labour. Very long to realise this type of drying leads to irregular products and is currently used in artisanal mining. Finally, we also have artificial drying which is carried out in industrial plants to ensure both gradual and regular heating ventilation. Drying is through rational conditioning the air used in evaporation, and adjusting humidity of air and ventilation.

\subsection{Formulation and Characterisation of Our Specimens Stabilised Mud Bricks}

Kaolinitic materials clay sampled in operating Makabaye and Pitoaré well were used in the formulation of stabilised mud bricks. The technological characteristics of ceramic products developed and permit, as shown by the results of work of physico-mechanical and geotechnical characterisation, to justify the use of raw materials in ceramic industry and the real estate sector [49]-[51].

As steps of formulation, we have preparation which includes formation of mixtures, removal of impurities, fragmentation, homogenization and humidification. Another step of formulation concern shaping and drying. Preparation of stabilised bricks operations are approximately the same as those used for production of baked products. However, some features are worth mentioning: $5 \%$ by weight of portland cement is added to mixture of natural materials disintegrated; when mixture "natural cement materials" is homogeneous, an amount of water is added uniformly until optimal humidity $(12 \%-15 \%)$. The shaping is carried out in a Proctor mold about an hour after addition of water to the mixture; the freshly molded blocks have two weeks to cure by covering with a plastic sheet.

\section{Results and Discussions}

\subsection{Geotechnical Identification Tests}

\subsubsection{Natural Water Content}

The determination of natural water content which is presented in Figure 1 is based on following formula:

$$
W=100(P h-P s) / P s
$$

With: $P h$, the weight of soil sample in its natural state; $P$ s, the weight of soil sample after heating in the oven at $105^{\circ} \mathrm{C}$ for 24 hours. This is dry net weight that is equal to difference of total dry weight of the tare weight used; $P h-P s=$ water weight [52]-[55].

It appears that the materials of Mayo-Tsanaga (Makabaye) have natural water contents sizeable $54 \%$ compared to those of Pitoaré which vary only $46 \%$. These changes in natural water content may be related to amount of fine clay or elements contained in analysed samples. The character of finer materials by Mayo-Tsanaga compared to Pitoaré is thus demonstrated.

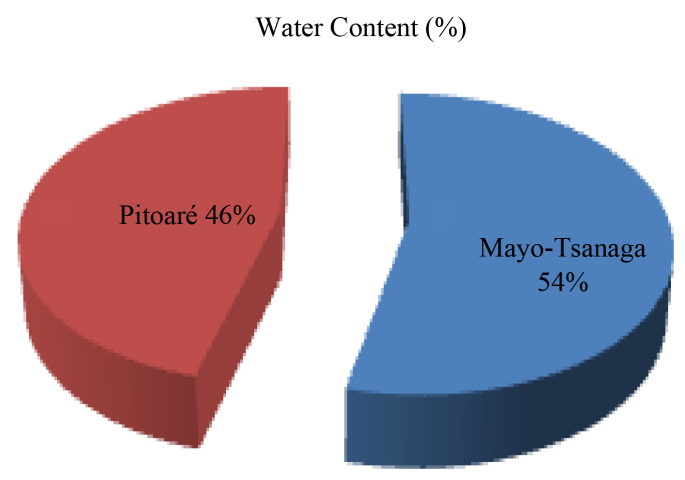

Figure 1. Change in the water content of the respective samples of Mayo-Tsanaga and Pitoaré. 


\subsubsection{Organic Content}

In field of ceramics and especially in area of brick, organic materials greatly affect the process of stabilisation and cooking, and thus the quality of finished products [52]-[55]. The Table 1 below shows levels of organic matter.

Samples were analysed for contents of less than $1 \%$ organic matter. They are thus very poor soil organic matter and are qualified geotechnically inorganic soil. Their negative effect on manufacturing processes of the bricks (stabilisation or baking), is therefore negligible.

\subsubsection{Equivalent Sand}

Produced on fraction of materials passing through sieve of $5 \mathrm{~mm}$, the test sand equivalent reflects overall quantity and quality of elements contained in the finer fraction, expressing a volumetric ratio of said conventional elements sand and finer (clay, for example). On the value of Sand Equivalent (ES) obtained, the soil is well qualified [52]-[55].

The results we have obtained in this trial allowed us to confirm the clayey soil found in the northern part of northern Cameroon, namely soils of Makabaye and those of Pitoaré. However, the analyses show an equivalent percentage of $14 \%$ sand for the two samples of soils studied. The Makabaye soils are also found that are sandyclayey nature from those of Pitoaré which are in turn very clayey.

\subsubsection{Size Analysis by Dry Sieving}

Adequate technological scope of materials clay shows in Figure 2 is strongly based on knowledge of their size characteristics.

Table 1. Levels of organic matter from natural materials of Mayo-Tsanaga and Pitoaré.

\begin{tabular}{cc}
\hline Sites & M.O\% \\
\hline Mayo-Tsanaga & 0.92 \\
Pitoaré & 0.79 \\
\hline
\end{tabular}

\section{Size analysis by dry sieving}

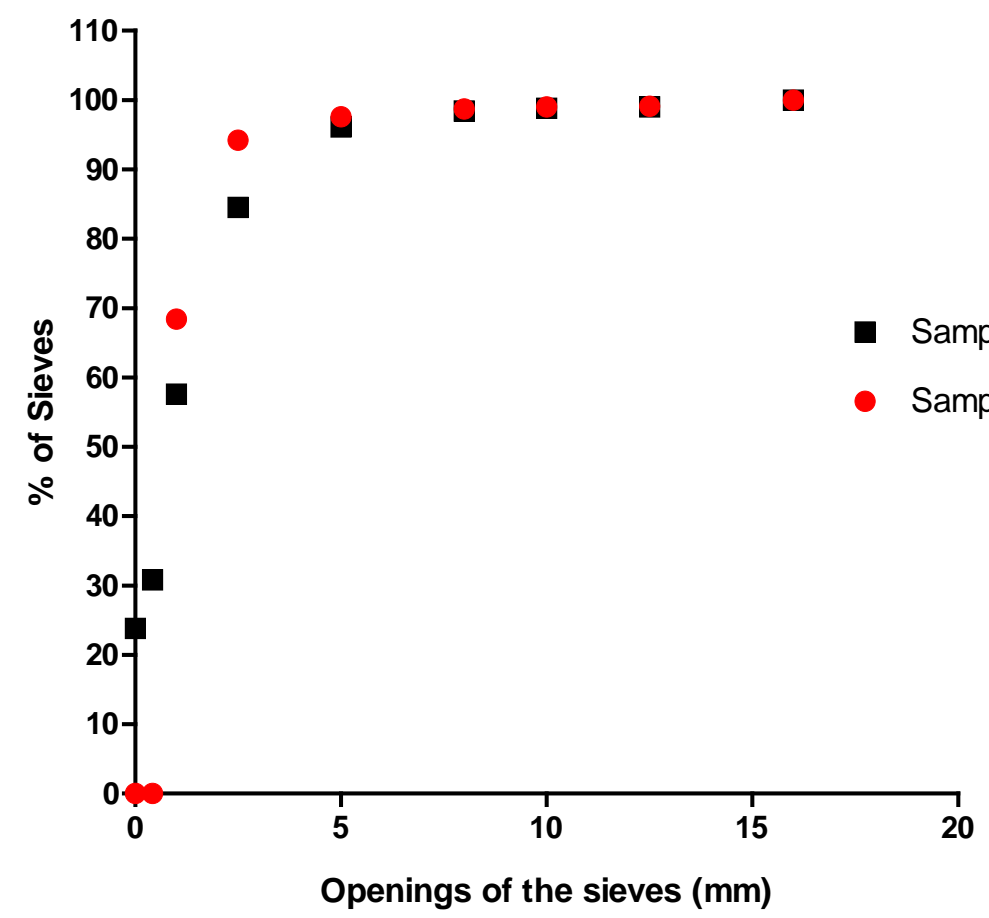

Figure 2. Conventional particle size curves of natural materials of Mayo-Tsanaga and Pitoaré. 
Makabaye materials consist only of particles size less than $5 \mu \mathrm{m}$. They passersby to screen much larger 2500 $\mu \mathrm{m}(99.7 \%)$; and consists of more than half (59.9\%) of particles smaller than $8 \mu \mathrm{m}$. They gave Accumulated $2500 \mu \mathrm{m}$ sieve $0.3 \%$ refusal. Which denotes end character more (clayey) of these materials. Pitoare materials consist only of particles size less than $10 \mathrm{~mm}$. They passersby to screen much larger $8000 \mu \mathrm{m}(99.1 \%)$; and consists of more than half (68.4\%) of particles smaller than $8 \mu \mathrm{m}$. They gave cumulative refusal $1.3 \% 2500 \mu \mathrm{m}$ sieve.

\subsubsection{Atterberg Limits}

Determining the liquid limit $\mathrm{W}_{\mathrm{L}}$ consisted of: expand on the cup, a sample in which a groove is drawn layer; print similar to the cup shock (due to 2 counts per second); collect in the cup, a certain amount of sample that is introduced into a known tare weight. The samples were dried in an oven over at least $105^{\circ} \mathrm{C}$; leave out of the oven, cool the samples in a desiccator and then weighed to obtain weight of dry sample + tare or $\mathrm{m}^{2}$. To determine plastic limit $\mathrm{W}_{\mathrm{P}}$, we drive spindle-shaped sample that gradually thins is the formation of the tubes. The plastic limit is water content of the time which is broken into small pieces, 10 to $20 \mathrm{~mm}$ long when its diameter reaches $3 \mathrm{~mm}$. These strands which are weighed before and after drying in an oven at more or less $105^{\circ} \mathrm{C}$ is sampled [52]-[55]. Table 2 below illustrates Atterberg limits of materials clay around Maroua.

The samples analysed correspond to fine-grained materials with at least $59.9 \%$ of passers- $8 \mu \mathrm{m}$ sieve mesh opening. Previously analysed samples, we are able to say that the materials for which $\mathrm{WL}<50 \%$ : Makabaye and Pitoaré; are clays (CL Group) inorganic thin, silty and/or sandy, relatively medium plasticity and semi-solid consistency. Materials samples MA and PI will thus likely to have strong withdrawals drying. The above observations, it emerges that analysed samples are materials useful mechanical behaviour, that can justify their use in field of construction and especially in brick industry and/or fine ceramics.

\subsubsection{Normal Modified Proctor}

The Proctor test is use to determine for: optimum moisture content leading to a maximum load capacity for a given soil and under conditions specific compaction; maximum density corresponding to a state of maximum compactness and capacity of maximum strength [52]-[55]. Table 3 below clearly summarise results of Modified Proctor Normal.

One can therefore realise the permanent change in water content of sample, during progressive addition of layers soil and compacting material using Proctor lady.

\subsubsection{CBR}

The California Bearing Ratio or C.B.R. is a dimensionless number expressing in percentage, the ratio of pressure producing a given material studied in one hand driving, and type material on the other. It is carried out on standard samples, saturated or unsaturated, reworked intact and in place on the ground [52]-[55]. That is what illustrates in Table 4 below.

Table 2. The Atterberg limits of materials clay around Maroua (Makabaye, Pitoaré).

\begin{tabular}{cccc}
\hline Sample & Limit Liquidity WL & Limit Plasticity WP & Index Plasticity IP \\
\hline Makabaye & 43.7 & 25.6 & 18.6 \\
Pitoaré & 43.6 & 25.3 & 18.3 \\
\hline
\end{tabular}

Table 3. Summary of results of the Modified Proctor Normal samples of Makabaye and Pitoaré.

\begin{tabular}{ccc}
\hline Sample & Water content W\% & Dry density max $\mathrm{T} / \mathrm{m}^{3}$ \\
\hline Makabaye & 11.3 & 2020 \\
Pitoaré & 10.5 & 2000 \\
\hline
\end{tabular}

Table 4. Results of the analysis C.B.R. samples of Makabaye and Pitoaré.

\begin{tabular}{cc}
\hline Sample & CBR\% \\
\hline Makabaye & $22 \%$ \\
Pitoaré & $36 \%$ \\
\hline
\end{tabular}


Percentages C.B.R. samples of Makabaye and Pitoaré are finally 36\% and 22\%. Pitoaré that of being high reflecting its ability to withstand relatively large loads.

\subsubsection{Measure of Specific Gravity Soil}

This test is intended to determine specific weight of soil using pycnometer. The specific gravity shows in Table 5 is defined as the weight per unit volume of solid particles of soil; the voids of soil, and water that could be included while not taken into account [52]-[55].

This reflects a considerable percentage of voids, see higher for samples Makabaye. Materials Clay Pitoaré is thinner more plastic, and therefore more clay.

\subsubsection{Measuring of Bulk Density Soil}

This is specific gravity of a solid floor (Ys) shows in Table 6, which is ratio of its weight of solid particles (Ws) to volume (Vs) particles they occupy. The weight of the solid particles is obtained by weighing. The volume of solid grains is measured by pycnometer or hydrometer [52]-[55].

The volume of grains materials clay Makabaye appears larger than Pitoaré. Reflecting the clay content of soils studied. A natural water content between $20 \%$ and $25 \%$ with a sand equivalent ranging from $10 \%$ to $14 \%$; Makabaye soils are materials clay (2\% to $32 \%$ clay) plastics (IP: 18.1 ; WL $<50 \%$; WS: $14 \%-21 \%$ ), inorganic (MO $<1 \%$ ), very robust (IC 1.79 ), thin, silty ( $11 \%$ - $42 \%$ silt), sand ( $14 \%$ to $32 \%$ of fine sand and $24 \%-35 \%$ coarse sands). Natural materials extracted from the Pitoaré site correspond to inorganic clay ( $\mathrm{MO}<1 \%$ ), fat, plastic consistency (CI 1.80), plastics (IP: 18.3; WS: 14\% - 21\%; WL <50\%). As for Makabaye materials, Pitoaré clay has a neighbor gravity of 2, 6 and a pH of between 4.00 and 4.33 .

\subsection{Technology Features: Drying Shrinkage Products}

The drying shrinkage percentages shows in Table 7 are obtained by difference between the lengths before drying (original length) and after drying (final length).

In light of these results, following observations can be drawn withdrawals determined average values normally encountered. Specimen's brick of Makabaye are highly plastic and presented too poor sand materials. Those Pitoaré titrate $8 \%$ on average; dry goods are perfect, no cracks were observed macroscopically during drying. Since specimens brick two pilot sites were subject to the same processing conditions (suffered the same degree of compression during formatting in Proctor mold) and drying (even humidity), the largest shrinkage values Makabaye products compared to those of Pitoaré are related to nature of clay component and fineness.

Specimens of cement stabilised mud bricks were manufactured and studied in laboratories. These ceramic products developed from kaolinitic materials clay extracted from artisanal mining Makabaye and Pitoaré wells,

Table 5. Specific weight of materials analysed in respectively areas of Mayo-Tsanaga and Pitoaré.

\begin{tabular}{cc}
\hline Sample & Specific sample weight (grams) \\
\hline Mayo-Tsanaga & 2.667 \\
Pitoaré & 2.302 \\
\hline
\end{tabular}

Table 6. Bulk density of the materials analysed in the respective areas of Mayo-Tsanaga and Pitoaré.

\begin{tabular}{cc} 
Sample & Bulk density \\
\hline Mayo-Tsanaga & 1.558 \\
Pitoaré & 0.993 \\
\hline
\end{tabular}

Table 7. Withdrawal drying experimental bricks Makabaye (MA) and Pitoaré (PI).

\begin{tabular}{ccccc}
\hline Specimens brick & $\mathrm{N}^{\circ}$ & Initial length $(\mathrm{mm})$ & Finale length $(\mathrm{mm})$ & Drying shrinkage $(\%)$ \\
\hline Makabaye & 1 & 172 & 160 & 10 \\
Pitoaré & 2 & 89 & 80 & 8 \\
\hline
\end{tabular}


Maroua in the Far North Region Cameroon. Technological and physico-mechanical characteristics of these products are very interesting to justify the use of basic materials in heavy ceramic industry (site Makabaye), or fine for the manufacture of products with higher added value, such as porcelain (website of Pitoaré), non-existent or too underdeveloped to Maroua in the Far North Region Cameroon.

For good industrial profitability, withdrawals observed in these specimens of bricks can be minimised by the addition of an optimal amount of degreaser, or revising upward drying temperature during product development [56]-[63].

\subsection{Physical and Technological Properties of Stabilised Mud Bricks}

Knowledge of geotechnical parameters materials clay also requires notions about physical and technological properties of studied clay. These include forming moisture, drying shrinkage and compressive strength that certifies performance of finished product (stabilised mud brick).

\subsubsection{Shaping Humidity Test: Results and Discussion}

It's to give the product optimal plastic consistency by moistening at optimum water content. Humidification bricks specimens vary with additive percentage and particle size cutoff used. Figure 3 below shown results obtain.

Based on previous results, Makabaye and Pitoaré samples are related to nature of clay component and fineness. An amount of water is added uniformly until optimal humidity (12\% - 15\%).

\subsubsection{Drying Shrinkage}

Determination of drying shrinkage percentages is obtained by difference between the lengths before drying (original length) and after drying (final length). This is also what we illustrated in Figure 4.

Samples bricks of Makabaye and Pitoaré presented poor sand materials. Dry goods are perfect and no cracks were observed macroscopically during dry process. We concluded that kaolinitic materials clay from Makabaye and Pitoaré are very interesting to justify the use of basic materials in heavy ceramic industry (site Makabaye), or fine for manufacture of products with higher added value, such as porcelain (website of Pitoaré).

\subsubsection{Mechanical Performance of Stabilised Mud Bricks}

The compressive strength or performance factor of a brick is determined for different percentage of cement. If we observe the Figure below, the values of resistance to compression show that cement percentage may perform properties bricks. We illustrated in Figure 5 obtain results.

This study shows that compressive strength is influenced by amount and percentage of cement embedded in the brick. Both materials clay Makabaye and Pitoaré can therefore be used as raw material in manufacture in-

\section{Variation of Shaping Humidity with Cement and its influence on technological properties of mud stabiliser bricks}

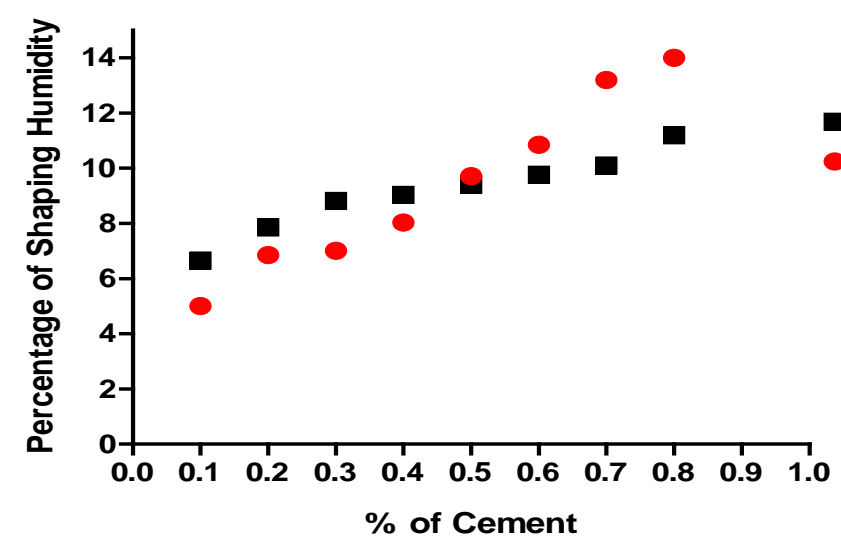

Figure 3. Influence of shaping humidity on technological characteristics of mud bricks Makabaye and Pitoaré. 
Drying Shrinkage on Technological properties of Mud Stabilised Bricks Makabaye and Pitoaré Area

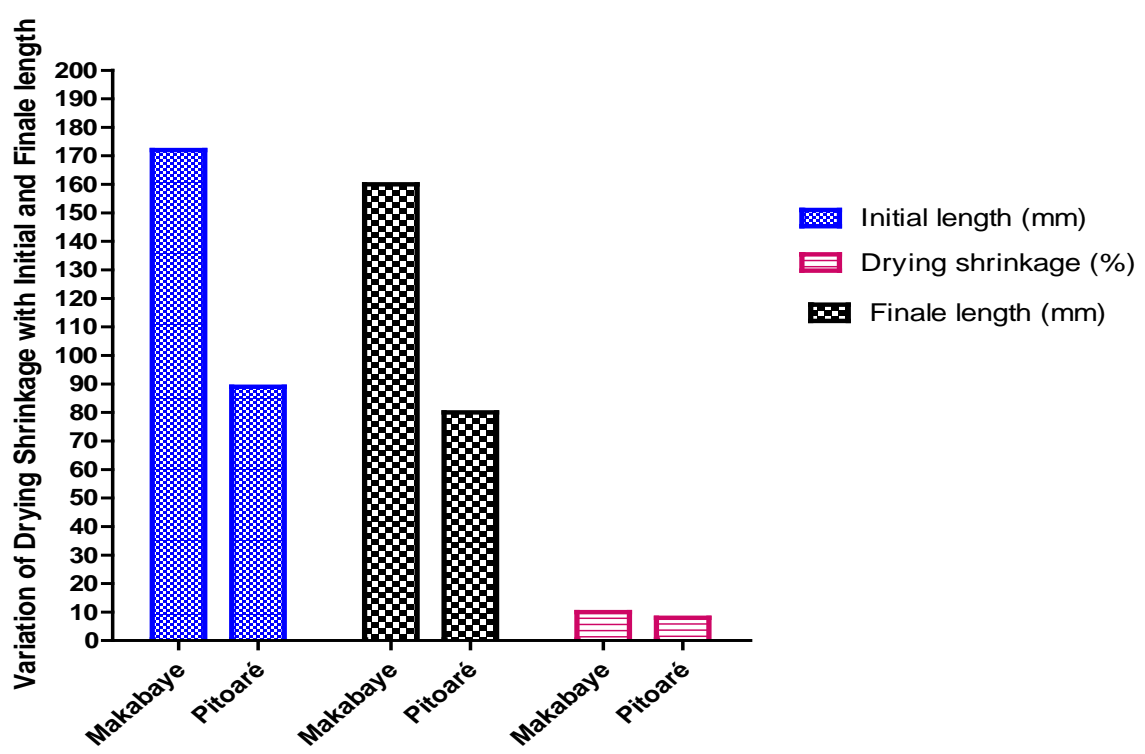

Figure 4. Influence of drying shrinkage on technological characteristics of mud bricks Makabaye and Pitoaré.

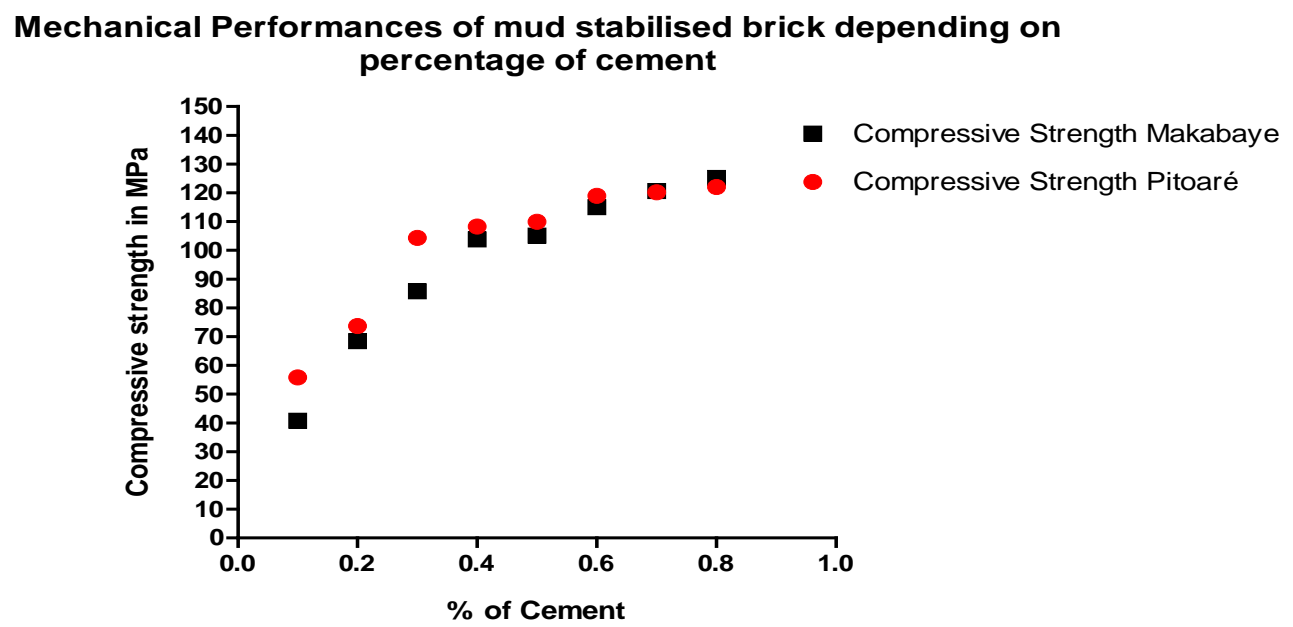

Figure 5. Influence of compressive strength on technological characteristics of mud bricks Makabaye and Pitoaré.

dustry of mud stabilised bricks.

Note, however, that the strength of bricks gradually increases with the addition of cement percentages. This may also be explained by the mechanical properties of the bricks that vary while the surrounding $120 \mathrm{MPa}$ and characterising the compressive strength between standard bricks. The addition of cement as adjuvant greatly affects the mechanical properties of stabilised bricks Makabaye and Pitoaré. This influence consequently improves hardness, hygroscopic and humidity parameters bricks. As can be seen on the graph, the mechanical properties Pitoaré bricks look better compared to those of Makabaye.

So we recommend an addition of cement in the proportions of $0.8 \%$ given the mechanical performance of stabilised mud bricks made from this formulation. The more cement proportion is high, excellent mechanical properties are obtained from brick clays Makabaye and Pitoaré.

Ultimately, the two samples studied soils are favorable and conducive to the making of bricks stabilised with 
defined proportions of cement, here playing the role of adjuvant. For soils Makabaye and Pitoaré, there are full potential features to value in the ceramics industry.

\section{Conclusions and Outlook}

This work based on implementation and production of compressed bricks made of Makabaye and Pitoaré clay. The physicochemical and geotechnical characterisations of argillaceous materials coming from the river of Mayo-Tsanaga (Makabaye) and Pitoaré in Maroua (Far-North region of Cameroun), is made with the aim of determining the physicochemical and mineralogical properties of clay. After the work of ground, the studies in laboratory concerned the classification tests of geotechnics (humidity degree, equivalent sand, Atterberg limits, particle size analyses, Proctor test and California Bearing Ratio test) and technological analyses (Drying shrinkage, Shaping humidity test, Mechanical performance) of the materials clay.

The samples analysed correspond to fine-grained materials with at least $59.9 \%$ of passers- $8 \mu \mathrm{m}$ sieve mesh opening. Previously analysed samples, we are able to say that the materials for which $\mathrm{WL}<50 \%$ : Makabaye and Pitoaré are clays (CL Group) inorganic thin, silty and/or sandy, relatively medium plasticity and semi-solid consistency. Materials samples Makabaye and Pitoaré will thus likely to have strong withdrawals drying. The above observations, it emerges that analysed samples are materials useful mechanical behaviour that can justify their use in field of construction and especially in brick industry and/or fine ceramics. The volume of grains materials clay Makabaye appears larger than Pitoaré. Reflecting the clay content of soils studied. A natural water content between $20 \%$ and $25 \%$ with a sand equivalent ranging from $10 \%$ to $14 \%$; Makabaye soils are materials clay (2\% to $32 \%$ clay) plastics (IP: 18.1 ; WL $<50 \%$; WS: $14 \%-21 \%$ ), inorganic (MO $<1 \%$ ), very robust (IC 1.79 ), thin, silty ( $11 \%-42 \%$ silt), sand (14\% to $32 \%$ of fine sand and $24 \%-35 \%$ coarse sands). Natural materials extracted from the Pitoaré site correspond to inorganic clay (MO < 1\%), fat, plastic consistency (CI 1.80), plastics (IP: 18.3; WS: 14\% - 21\%; WL < 50\%). As for Makabaye materials, Pitoaré clay has a neighbor gravity of 2, 6 and a $\mathrm{pH}$ of between 4.00 and 4.33 .

Kaolinitic materials clay sampled in operating Makabaye and Pitoaré well were used in the formulation of stabilised mud bricks. The technological characteristics of ceramic products developed and permit, as shown by the results of work of physico-mechanical and geotechnical characterisation, to justify the use of raw materials in ceramic industry and the real estate sector. Samples bricks of Makabaye and Pitoaré presented poor sand materials. Dry goods are perfect and no cracks were observed macroscopically during dry process. We concluded that kaolinitic materials clay from Makabaye and Pitoaré are very interesting to justify the use of basic materials in heavy ceramic industry (site Makabaye), or fine for manufacture of products with higher added value, such as porcelain (website of Pitoaré).

The use of white clay Makabaye and Pitoaré is not limited to ceramic products or building materials. Sound treatments applied to these materials would consider their development in fields as diverse as mineral filler composite materials (pulp and paper, inks and paints, plastics), manufacturing, pharmaceuticals, health and cosmetics. Given the human occupations (construction, cultures) say anarchic increasingly growing in the town of Maroua (Makabaye and Pitoaré), its potential kaolin clay should be quantitatively assessed to enable public authorities to take good decisions related to semi-industrial or industrial exploitation of these clay we call "noble".

In addition, the project is expected to also focus on analysis of the life cycle of all products involved in process of ceramic production, the flow of materials and energy. By this method, it is possible to quantify the potential environmental impacts of these products from the extraction phase of the raw materials clay through the manufacturing process, to the marketing and use of ceramic materials manufactured. Conducting such an assessment can also help valorisation and develop products with the lowest impacts. Standardised and recognised tool, analysis of the life cycle is currently the most successful method in terms of global and multi EA. In this dynamic characterisation studies and promotion of local building materials should be supported and involve technological innovation.

\section{References}

[1] Circular No. 002/CAB/PM of 12 March 2007 on the Use of Local Materials in the Construction of Public Buildings to $\mathrm{R}+1$.

[2] Minla Mfou'ou, J. (2006) Decentralisation, an Opportunity to Improve the Development and Local Governance. 
Common Examples in Cameroon, Expenditure of Initiatives Group.

[3] (2007) Masters Series Community Project.

[4] Tobie Hond, J. (2011) Decentralisation and Strengthening of Local Governance Capacities: A Policy and National Development Strategy. The Experience of Cameroon, Tangier.

[5] Bral, C., Dufourni, L. and Van den Bossche, J. (2007) Terracotta and Engineering. No. 119, Lannoo Drukerry, Brussels.

[6] Coulombel, J., Duquenoy, M. and Terrones, O. (2010) Earthen to Construct. Europe and the Environment.

[7] Association of Belgian Brick (2006) Terracotta Brick-The Choice of Sustainable Construction. Rue des Chartreux, Brussels.

[8] Association of Belgian Brick (2008) Bricks Manual. Ruedes Chartreux, Brussels.

[9] Gilles, B. (2009) Brick and Sustainable Development. GIE BATC Billbrickclay, Paris.

[10] Guillaud, H., Joffroy, T. and Reward, P. (1995) Volume 2, Design and Construction Manual, CRATerre-EAG.

[11] Kornmann, M. (2005) Clay Building Materials. Preparation and Properties, Mars, SEPTIMA Editions.

[12] Rigassi, V. (1995) Volume 1 of the BTC Production Manual, CRA Terre-EAG.

[13] Alcântara, A.C.S., Beltrão, M.S.S., Oliveira, H.A., Gimenez, I.F. and Barreto, L.S. (2008) Characterization of Ceramic Tiles Prepared from Two Clays from Sergipe-Brazil. Applied Clay Science, 39, 160-165.

[14] Morel, C., Alexanian, P. and The Majority, L. (1966) The Infrared Absorption Spectra of Natural Minerals. Bulletin Society of Ceramics, 3.

[15] Arib, A., Sarhiri, A., Moussa, R., Remmal, T. and Gomina, M. (2007) Structural and Mechanical Properties on the Basis of Sound: Influence of the Source of Feldspar. CR Chemistry, Science Direct, 502-510.

[16] Bailon, J. and Dorlot, J. (2000) Minerals. 3rd Edition, Presses Internationales Polytechnique, Montreal, 1-736.

[17] Bakam, A., Kordikontar, K.M. and Laterite, I. (2004) Stabilization Test with the Cellulosic Fibers. African Journal of Science and Technology, Science and Engineering, 1, 22-28.

[18] Suits, L.D., Sheahan, T.C., Wen, B., Aydin, A. and Duzgoren-Aydin, N.S. (2002) A Comparative Study of Particle Size Analyses by Sieve-Hydrometer and Laser Diffraction Methods. Geotechnical Testing Journal, 25.

[19] Neira, J.B., Monte, A.L. and Romerol, L.L. (2009) Ceramics of Ategua (Córdoba, Spain): Mineralogical and Petrographic Study. Applied Clay Science, 42, 529-537.

[20] Goose, A. (1993) Physical Chemistry Sintering. Editions Hermès, Paris, 1-147.

[21] Bloodworth, A.J., Highley, D.E. and Mitchell, C.J. (1993) Industrial Minerals Laboratory Manual: Kaolin. Technical Report, 1-76.

[22] Hassan, A. and Abdelkar, F. (2007) Manuel of Hands Soil Mechanics. University Publication Center, Tunis, 116.

[23] Brindley, G.W., Kao, C.-C., Harrison, J.L., Lipsicas, M. and Raythatha, R. (1986) Relation between Structural Disorder and Other Characteristics of Kaolinites and Dickites. Clays and Clay Minerals, 34, 239-249. http://dx.doi.org/10.1346/CCMN.1986.0340303

[24] Brindley, G.W. and Nakahira, M. (1959) The KaoIinite-Mullite Reaction Series: I, A Survey of Outstanding Problems. Journal of the American Ceramic Society, 42, 311-314.

[25] Brown, G. and Brindley, G.W. (1980) X-Ray Diffraction Procedures for Clay Mineral Identification. In: Brown, G. and Brindley, G.W., Eds., Crystal Structures of Clay Minerals and Their X-Ray Identification, Mineralogical Society, London, 305-359.

[26] Bertrand, G. and Pirraud, B. (1982) Clay Mineralogy, II: Classification and Nomenclature. Masson, Paris.

[27] Calabria, J.A., Vasconcelos, W.L. and Boccaccini, A.R. (2009) Microstructure and Chemical Degradation of Adobe and Clay Bricks. Ceramics International, 35, 665-671.

[28] Carty, W. (1999) The Colloidal Nature of Kaolinite. The American Ceramic Society Bulletin, 78, 72-76.

[29] CERAMeUNIE (2003) Suggested Best Available Techniques (BAT) Document for the European Ceramics Industry.

[30] CERATEC (1987) Earth Blocks Stabilized, Production Technology, 31.1.

[31] Chen, C.Y., Lan, G.S. and Tuan, W.H. (2000) Preparation of Mullite by the Reaction Sintering of Kaolinite and Alumina. Journal of the European Ceramic Society, 20, 2519-2525. http://dx.doi.org/10.1016/S0955-2219(00)00125-4

[32] Christidis, G. (2011) Industrial Clays. Notes in Mineralogy, Volume 9, Mineralogical European Union, 341-414.

[33] Sanglerat Costet, J.G. (1981) During the Soil Mechanics Practices, Volume 1, Plasticity and Calculation of the Settlement. Dunodedition, Paris, 1-339.

[34] CRATerre (1991) Pressure Earth Blocks, Foundations, Eschborn, GATE, 27.1. 
[35] CRAterreCDI (1996) Pressure Earth Blocks Process Equipment.

[36] CRATèrreEAG (1995) Pressure Earth Blocks. Production Manual, Eschborn, GATE.

[37] Delon, J., et al. (1982) Employment Opportunities in the Charente Kaolin Cast Paper and Cardboard. Bulletin of Mineralogy.

[38] Djangang, C.N., Elimbi, A., Melo, U.C., Lecomte, G.L., Nkoumbou, C., Soro, J., et al. (2008) Sintering of ClayChamotte Ceramic Composites for Refractory Bricks. Ceramics International, 34, 1207-1213.

[39] Dondi, M., Marsigli, M. and Venturi, I. (1999) Microstructure and Mechanical Properties of Clay Bricks: Comparison between Fast Firing and Traditional Firing. British Ceramic Transactions, 98, 12-18.

[40] Callaud, A. (1993) Introduction to the Study of Industrial Clays of Cameroon. Annals of Faculty of Sciences, University of Yaoundé, Yaoundé, 11-16.

[41] Fagela, N., Boski, T., Likhoshway, L. and Oberhaensli, H. (2003) Late Quaternary Clay Mineral Record in Central Lake Baikal (Academician Ridge, Siberia). Palaeogeography, Palaeoclimatology, Palaeoecology, 193, $159-179$.

[42] Ferd, S. (2004) Ceramic Guides, Standards and Specifications. Sion and Monthey, 1-11.

[43] Gonzalez, I., Galan, E., Miras, A. and Aparicio, P. (1998) New Uses for Brick-Making Clay Materials from the Bailen Area (Southern Spain). Clay Minerals, 33, 453-465.

[44] Guerraoui, F., Zamama, M. and Ibnoussina, M. (2008) Mineralogical and Geotechnical Characterization of Clays Used in Ceramics in Safi (Morocco). African Journal of Science and Technology, Science and Engineering Series, 9, 1-11.

[45] Guggenheim, S., Adams, J.M., Bain, D.C., Bergaya, F., Brigatti, M.F. and Drits, V.A. (2006) Summary of Recommendations of Nomenclature Committees Relevant to Clay Mineralogy: Report of the Association Internationale pour l'Etude des Argiles (AIPEA) Nomenclature Committee for 2006. Clay Miner, 41, 863-877.

[46] Good Plowman, D. (1993) Air Respond Buildings, Built Suitable Buildings in Tropical and Subtropical Areas. Publications SKAT.

[47] Harben, P. (1999) The Industrial Minerals Handybook: A Guide to Markets, Specifications \& Prices. Minerals International Information Ltd.

[48] Hart, J.R., Zhu, Y. and Pirard, E. (2011) Particle Size and Shape Characterization: Current Technology and Practice. In: Christidis, G.E., Ed., Advances in the Characterization of Industrial Minerals, Volume 9, Mineralogical Society of America, 77-127.

[49] Harvey, C. and Murray, H. (1997) Industry-Tone in the 21st Century. A Perspective of Research, Technology and Application. Applied Clay Science, 285.

[50] Hetier, J.M., Yoshinaga, N. and Weber, F. (1977) Formation of Clay Minerals in Ando-Soils under Temperate Climate. Clay Minerals, 12, 299-307.

[51] Holtz, R. and Kovacs, W. (1991) Introduction to the Issue Polytechnic of Montreal, Quebec. Geotechnical Engineering, 808.

[52] Guillaud, H. and Hermann, H. (1989) Construction Contract Earth. Volume 1, Editions Brackets, Paris, 1-355.

[53] Humbel, F. (1965) Studies of Saline Soils of Northern Cameroon (Maroua). Yaoundé ORSTOM, Paris, 68.

[54] Ibnoussina, M., et al. (2004) Geotechnical Behavior of Clays Autumn Brown Clay Lalla Fatna (Safi, Morocco). Annals Society Geology of North.

[55] Jouenne, C. (1984) Contract and Ceramic Materials. Editions Septima, Paris, 1-657.

[56] Jordan, A. (1966) The Technology of Refractory Ceramic Products. Editions Gauthier-Villard, Paris, 1-590.

[57] Kabre, S., Traore, K. and Blanc, P. (1998) Mineralogy of Clay Raw Material from Burkina Faso and Niger Used for Ceramic Wares. Applied Clay Science, 12, 463-477.

[58] Kamseu, E., et al. (2007) Characterization of Porcelain Compositions Use of Two Clays from Cameroon China. Ceramics International, 851-857.

[59] Kornman, M. (2005) Clay Building Materials. Edition Septima, Paris, 1-275.

[60] Ligas, P., Uras, I., Dondi, M. and Marsigli, M. (1997) Kaolinitic Materials from Romana (North-West Sardinia, Italy) and Their Ceramic Properties. Applied Clay Science, 12, 145-163.

[61] Belkacemi Merabet, D. H. (2003) Mineralogical and Chemical Characterization of Kaolin Tamazert (Algeria). Annales De Chimie-science Des Materiaux.

[62] Mitchell, D. and Vincent, A. (1997) Exploration and Evaluation of Plastic Sedimentary Clays for the Fine Ceramics Industry. Vol. 2.

[63] Mpelle, M. (1997) Formulation Experiments the Production of Ceramic Tiles of Clay Yaoundé. Journal Cameroon of Building Materials, 1, 16-20. 